\title{
THE NEED FOR MICROBIAL ECOLOGISTS
}

厂

n 1954 the chairman of the Beecham Group, Henry Lazell, went in search of some good advice. Against the instincts of some of his colleagues, he felt that Beechams should diversify away from the acrossthe-counter nostrums and toiletries which had long been their stock-in-trade. They should invest in research. And the most obvious temptation was to do what many other pharmaceutical companies were doing at that time: screen multitudes of Actinomyces and Streptomyces strains in the quest for new antibiotics. Lazell-a shrewd accountant who had risen from the humblest beginnings - decided instead to see whether Sir Charles Dodds, a Beecham consultant, had any better ideas. He, in turn, recommended an approach to Ernst Chain, then working in Rome after falling out with Britain's establishment over the patent rights in the penicillin he and Howard Florey had developed.

The rest, as they say, is history. Chain argued that there was no point in joining the hunt for more naturally occurring antimicrobials. He suggested instead that Beechams should set up a programme to evolve semi-synthetic penicillins, made by modifying chemically the products of biosynthesis. Lazell agreed. And just five years later the first of them was marketed. By 1962 the company's sales revenue from antimicrobials (which had been nil 10 years earlier) had reached $£ 3,100,225$ (\$4.9 million).

With broader horizons, made possible by the advent of gene-splicing techniques, many biotechnology organisations today find themselves in a position like that facing Beechams during that first golden age of antibiotics Certain obvious lines of $\mathrm{R} \& \mathrm{D}$ are already apparent. A mere handful of key products are attracting disproportionate attention. And even discussion of future trends tends to be along familiar lines. The question is: what will prove to be the unexpected winners? Looking back, 30 years hence, which strategies and stratagems will have brought the sort of commercial and scientific dividends which stemmed from that inspired, unlikely, risky, partnership between a self-made captain of industry and an irascible German-Jewish biochemist?

My own feeling is that the most spectacular rewards will accrue to those who are now doing some lateral thinking. And one of the most prolific strands of thought could mean switching attention from desirable end-products (interferon, insulin ...) and processes (efficient biomass conversions ...) to the astronomical range of putative producers among the microbial talent already available to us. In other words, as well as exploiting recombinant DNA manipulations to improve the nature and yield of predictable materials, we should be re-

Bernard Dixon, Ph.D. is a microbiologist and regular columnist for $\mathrm{BIO} /$ TECHNOLOGY. He is a former editor of New Scientist. viewing the extraordinary creativity of submicroscopic life and contemplating possible uses for skills which lie well beyond those of human chemists. Most of the winners, I predict, will be those biotechnology teams which have had a microbial ecologist on board.

"Chromobacterium violaceum was living in relative obscurity in the swamps of southern New Jersey only three years ago," wrote John Henahan recently in the Journal of the American Medical Association $(\mathbf{2 4 8}, 2085)$. Today, as he pointed out, a new drug developed as a result of the discovery of this bacterium is proving to be a potent weapon against otherwise intractable gram-negative infections. In this case, an organism's ability to produce a weak antibiotic, but one highly resistant to $\beta$-lactamases, prompted chemists to synthesise the new molecular variant, now called azthreonam.

Away from the well-worn area of antibiotics (well-worn but still generating novelties like this one) there must be countless other potentially invaluable bacteria, fungi and other microorganisms which are also reproducing in relative or total obscurity. Consider, for example, the garden pest Erwinia rhapontici. According to Bergey's Manual of Determinative Bacteriology its sole activities are: "Rots onion and cucumber slices; potato slices are rotted slightly or not at all. Causes a crown rot of rhubarb." Who would have dreamed that this tiresome plant pathogen could be useful to the food industry? The answer is Dr. Peter Cheetham and his colleagues at Tate \& Lyle, who have found (Nature, 299, 628) that $E$. rhapontici generates a "new" sugar, isomaltulose, use of which could prevent dental caries. They have already harnessed its immobilised cells to produce isomaltulose in high yields, and believe the process has a commercial future.

It is very tempting to generalise from this experience and to speculate about the cornucopia of microbial talent which is as yet unexploited or unrecognised. Some indication of the dimensions of that reservoir of versatility can be gained by considering the new discoveries reported during just a single year, 1982. Biochemically, these

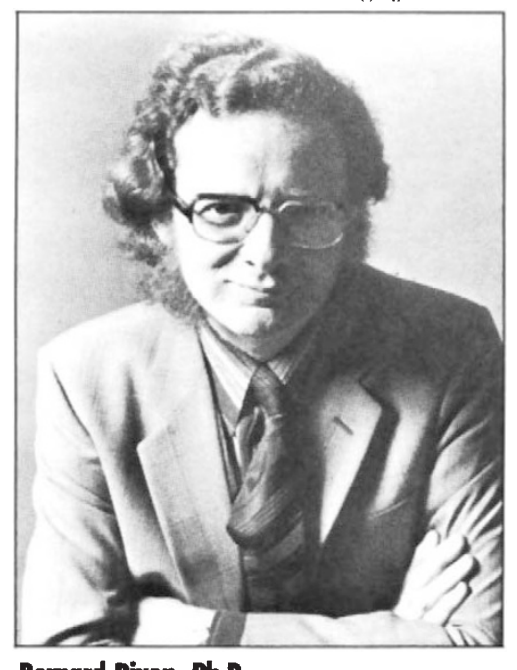

Bemerd Dixon, Ph.D. ranged from the methylation of tin by estuarine micro-organisms (L. E. Hallas et al, Science, 215, 1505) to the anaerobic biodegradation of haloaromatics in lake sediment (J. M. Suflita et al, Science, 218, 1115). Ecologically, they embraced bacteria thriving at $105^{\circ} \mathrm{C}$ in the Mediterranean seabed (K. O. Setter, Nature, 300, 258) and the rich microbial life of the frozen Antarctic (E. I. Friedmann, Science, 215, 1045). And in terms of behaviour they included a virus, pathogenic in rice, which promotes rather than retards the growth of other plants $(\mathrm{S}$. K. Ghosh, Planta, 155, 193), and bacteria which act as the propulsive system for protozoa in the hind gut of the wood termite (S. L. Tamm, Journal of Cell Biology, 94, 697)

Continued on page 131 
FINAL WORD Continued from page 132

ignored, many mistakes will be made. The information is there for the asking. The International Centre cannot afford to repeat the learning curve.

Then, the matter of funding must be addressed seriously, for that, ultimately will determine whether or not the International Centre is to be. It may be difficult to build and sustain the Centre solely from contributions from national governments. Why not also explore the possibility of at least partial corporate funding for the Centre? It could also enter into contracts and partnerships with private companies, either to fund or undertake work in needed areas.

The wealthy and developed industrial countries would, of course, help a great deal. But why should these countries care? Foreign aid has always been inspired by the "national interest" far more than altruism. But certainly, greater economic independence will make any nation less vulnerable to imperialism and internal corruption, and that is certainly in the best interests of the United States.

With the decisions on the International Centre still some distance in the future, there is still plenty of time for the United States to get involved. Its participation could do much to ensure the success of the Centre and, ultimately, to the world standard of living. Surely it is worth it.

COMMENTARY Continued from page 45

Each of these "finds" prompts ideas about means of making use of such bizarre abilities. A newly recognised thermophile, for example, could provide unusually stable, high catalytic activity encymes for industrial use. And a virus which is a pathogen in one plant might easily transform the production of other, high-fibre crops. But again, it is the less apparent applications that could have the most far-reaching consequences. What counts is the principle. While the chemical industry plays molecular roulette on known themes, our planet's teeming microbial life remains largely ignored as the source of an infinite range of possibilities

In their recent book Extinction, Paul and Anne Ehrlich give a telling analogy. As you are about to board an aeroplane, you notice a man removing rivets from its wings. He's taken out lots before without hazard, he assures you. But the thirtieth rivet gone from a wing flap could mean disaster. So too, the Ehrlichs argue, could the loss of any one plant or animal species that is pivotal to the complex web of life on earth. That message was directed at the conservation and ecological instincts of their readers. It could just as easily be aimed at biotechnologistswhether seeking understanding, or profit, or both.

\section{CORRESPONDENCE}

$\mathrm{BIO} / \mathrm{IECHNOLOGY}$ invites its readers to respond to all editorials, articles, research papers, or any current events in biotechnology which affect the lives of our readers. Short summaries of original research developments are also welcome. Beginning with the April issue, these letters will be published under Correspondence. Letters should be addressed to the editor and sent to: BIO/TECHNOLOGY, 15 East 26th St., New York, New York 10010.

BIO/TECHNOLOGY also welcomes proposals by scientists to provide interpretive reports on international meetings which they attend within their specialties. Requests should be submitted directly to the editor.

\section{Biotechnology Patent Digest}

. .COMPREHENSIVE, FAST, AND COST-EFFECTIVE

BIOTECHNOLOGY PATENT DIGEST, a bi-weekly periodica providing information on patents in biotechnology and related fields in an understandable format, is faster than on-line information sources, provides full-text information, and is the most costeffective source of patent information found anywhere

\section{Features include:}

- RECENT PATENTS - Patents issued during the previous two weeks are listed and essential information is presented in a concise format for easy scanning. Keywords alert you to patents of interest.

- PATENT HIGHLIGHTS - Patents describing major advances in general methodology, new processes, or new products are highlighted. Selected information may include claims, experimental (examples of the art), and drawings.

- RELATED PATENTS - Patents from related fields and technologies are presented permitting you to compare biological and conventional technologies.

- PATENTS FROM THE PAST - Important patents in biotechnology issued in past decades are described and even reproduced in original form. Section provides a historical perspective to new patents and documents past achievements. Best available copies are reproduced.

- PATENT DECISIONS AND RULINGS - Decisions by major patent organizations and rulings by courts are described in an abbreviated and understandable form. Section presents legal aspects to scientists and research administrators in relatively free non-technical language.

- PATENTS AVAILABLE FOR LICENSING - Patents available for licensing are listed.

- INVENTOR'S WORD - Personal accounts of major inventions and developments by inventors are given to stimulate discussion and improve the innovation process.

- NEWS BRIEF - General items of interest appear - new publications, forthcoming conferences, activities of scientific societies and trade associations, file intelligence, etc.

\section{Special Feature:}

- PATENT ANALYSIS - Brief but highly informative analyses of major techniques, processes, products, firms, and industrial sectors are presented.

OSKAR R. ZABORSKY, EDITOR U.S. NATIONAL SCIENCE FOUNDATION Washington, D.C., U.S.A. EDITORIAL BOARD
ROBERT W. COUGHLIN

University of Connecticut

ARNOLD LL DEMAIN

ARsachusetts institute

of Technology

RALPH W. F. HARDY

E. I. du Pont de Nemours

\& Company

ZSOLT HARSANYI

E. F. Hutton \& Co., InC

ALEXANDER HOLLAENDER

Council for Research Planning

in Biological Sciences

DALE H. HOSCHEIT

Schuyler, Banner, Birch,

McKie \& Beckett

If you're interested in biotechnology, then

BIOTECHNOLOGY PATENT DIGEST is for you!

- COMPREHENSIVE - presents full-text information from patents comprehensive coverage not obtainable from any other source except original patents. All relevant sectors of biotechnology - both traditional original patents. All relevant sect

- FAST - presents information as soon as it is made publicly available.

FAST - presents information as soon as it is made publicly availa

- COST-EFFECTIVE \& SELECTIVE - highlights significant patents in

biotechnology and related fields. Yet your cost is only a few dollars
bet biotechnology and
$(\$ 4.90)$ per week.
The Digest (ISSN 0730-1057) is available from the OMEC Publishing The Digest (ISSN 0730-1057) is available from the OMEC Publishing
Company, P.O. Box 446, McLean, VA 22101. Subscription price is $\$ 255$ per year (26 issues) for U.S. and Canada; $\$ 285$ per year elsewhere (including air delivery). Sample copies available. Circle No. 6 